\title{
"Susana e os velhos" em questão: um episódio bíblico, suas representações e relações com o governo da justiça no Antigo Regime (séculos XVI-XVIII)
}

"Susanna and the Elders" in question: a biblical episode, its representations and
relations with the government of justice in the Ancien Régime (16 $6^{\text {th }} 17^{\text {th }}$ centuries)

hitps://doi.org/10.1590/1982-02672021v29e22

\section{FERNANDA DEMINICIS DE ALBUQUERQUE²}

https: / / orcid.org/0000-0003-2704-7426

Universidade Federal Fluminense / Rio de Janeiro, RJ, Brasil

\section{MARCELLO JOSÉ GOMES LOUREIRO3}

https:/ / orcid.org/0000-0002-4394-340X

Universidade Federal Fluminense / Rio de Janeiro, RJ, Brasil

RESUMO: A partir do episódio bíblico conhecido por "Susana e os velhos", que consta no livro de Daniel, este artigo propõe um conjunto de questões para discutir as razões pelas quais essa história foi tão representada por pintores, sobretudo entre meados do século XVI e a centúria seguinte, em diversas regiões da Europa. $\bigcirc$ argumento axiológico é o de que esse episódio estabelece relações estreitas com o exercício da justiça e do direito régio, exatamente em uma conjuntura em que as monarquias europeias buscavam não apenas conferir centralidade ao governo da justiça, mas também instrumentalizar a arte como tecnologia potencial para suas soluções de lidimidade e de conservação. No plano conclusivo, o artigo sustenta a ideia de que o episódio era manipulado, na esfera moralizante, para disciplinar comportamentos sociais, sobretudo de mulheres; enquanto, na esfera jurídica, para ferir a legitimidade da aplicação de justiças sumárias ou particulares, fortalecendo a primazia de um direito régio.

PALAVRAS-CHAVE: Susana e os velhos. Representações do poder. Justiça régia.
1. Essa pesquisa é financiada com recursos da chamada universal 01/2016, CNPq (Edital 01/2016 - Processo 425900/2016-9). Agradecemos o diálogo profícuo e as valiosas sugestões de Marcelo da Rocha Wanderley, Pedro Calafate e Rodrigo Bentes Monteiro.

2. Doutoranda pelo Programa de Pós-Graduação em História da Universidade Federal Fluminense (PPGH-UFF). Mestre pelo Programa de Artes \& Design da Pontifícia Universidade Católica do Rio de Janeiro (PUC-Rio). E-mail: $<$ fernanda.deminicis@gmail. com>.

3. Doutor em História e Civilização pela École des Hautes Études en Sciences Sociales (EHESS) e doutor em História Social pelo Programa de Pós-Graduação em História Social da Universidade Federal do Rio de Janeiro (PPGHIS-UFRJ). Pós-doutor em História pelo Programa de Pós-Graduação em História da Universidade Federal Fluminense (PPGH-UFF). E-mail: $<$ marcelloloureiro@yahoo. com.br>. 
ABSTRACT: Based on the biblical episode known as "Susanna and the Elders", contained in the book of Daniel, this article proposes a set of questions to discuss the reasons why this history was so represented by painters, especially between the mid- $16^{\text {th }}$ and the following century, in several regions of Europe. The axiological argument is that this episode establishes close relations with the exercise of the king's justice, exactly at a time when European monarchies sought not only to give centrality to the government of justice, but also to instrumentalize art as a potential technology for its solutions for legality and conservation. In conclusion, the article reaches the idea that the episode was manipulated, in the moralizing sphere, to discipline social behaviors, especially of women; while, in the legal sphere, to undermine the legitimacy of applying summary or private justice, strengthening the primacy of a king's justice.

KEYWORDS: Susanna and the Elders. Representations of power. King's justice. 
Uma linda mulher que se banha ao ar livre em isolamento. Na busca de alguma privacidade, escolhe um jardim fechado. No entanto, secretamente, é acompanhada e observada por dois anciões. Seria apenas uma intenção ordinária de violação? Não somente isso; trata-se, de modo mais alargado, do episódio "Susana e os velhos", consignado no livro bíblico do profeta Daniel. Contudo, por que esse tema poderia ser objeto de tamanho interesse nas representações de diversos artistas a partir de meados dos quinhentos? Seria essa uma questão de disciplina social, a partir da crítica a um comportamento inaceitável de uma mulher que, ao se banhar, provoca intenções reprováveis até mesmo em idosos? $\bigcirc u$, de outra parte, uma advertência moral àqueles que não respeitam a intimidade de uma mulher casada? Do que se trata essa história? Por que se tornou tão repisada entre os séculos XVI e XVII? Seria porque se refere a um tema nevrálgico, como uma possível reflexão sobre os modos legítimos de julgamento e administração da justiça comutativa em uma certa sociedade? Nesse caso, quais suas possíveis relações com o governo da justiça?

Segundo o livro de Daniel, a virtuosa Susana, muito religiosa, era mulher de Joaquim, judeu rico e respeitado na Babilônia. Naquele tempo, haviam sido nomeados dois juízes, chefes de família, para serem conselheiros e guias do povo; dois anciões que já muito tinham visto e ouvido, e cuja sabedoria se inscrevia e se creditava no tempo.

Os velhos juízes costumavam frequentar a casa de Joaquim, onde frequentemente eram procurados pelo povo, que thes demandava amparo e conselho. Os juízes, ao verem cotidianamente os movimentos de Susana, passaram a cobiçá-la secretamente. Com perfídia, buscavam uma oportunidade de encontrála desacompanhada e distraída; encontraram essa ocasião em um dia de calor, quando Susana decidira se banhar. Dessa forma, às criadas, Susana ordenou que fossem buscar óleos e perfumes, e, acreditando-se sozinha, que fechassem as portas do jardim de Joaquim. A oportunidade parecia perfeita aos velhos.

Sem demora, os juízes abordaram e ameaçaram Susana: "concorde conosco. Se não concordar, nós acusamos você". 4 Susana estava ciente das consequências de tal acusação, mas apenas suspirou, decidindo não se submeter aos desejos dos velhos, preferindo enfrentar seu trágico destino a cometer um pecado. Ela então gritou, os velhos gritaram, e todos que estavam ali por perto adentraram os jardins. Os velhos alegavam ter visto Susana em pecado com um jovem rapaz, que teria thes escapado exatamente por ser mais forte e vigoroso.

Dessa maneira, todo o povo se reuniu em assembleia para ouvir o depoimento dos experientes juízes. Os simples testemunhos de ambos foram suficientes para que
4. Bíblia, Livro de Daniel, $13: 20$. 
5. Ibid., 13:41.

6. Ibid., 13:42-43.

7. Alude-se às passagens: "Deus dirige e julga a história" (Ibid., 7:9) e "Resistir até o fim" (Ibid., 9:1).

8. Ibid., 13:49.

9. Ibid., 13:61.

10. Conforme o mandamento: "não levantar falso testemunho".

11. Ibid., 13:64.

12. Cf. Baxandall (2006). todos acreditassem em suas palavras, afinal "eram anciões e juízes do povo". 5 Do testemunho público, resultou a condenação da pobre Susana à morte.

Ainda segundo o livro de Daniel, como último recurso, Susana olhou para o céu, clamando em alta voz a seu Deus "que conheces o que está escondido e tudo vês antes que aconteça", e afirmou: "tu sabes muito bem que eles deram falso testemunho contra mim". ${ }^{6}$ Em face da fortaleza de Susana, que antes optara por enfrentar os velhos, Deus demonstrou que dirige e julga a história, atendendo as súplicas daqueles que são capazes de resistir até o fim.?

Enquanto Susana era conduzida para a morte, Deus despertou o espírito de um jovem, cujo nome era Daniel, que deteve o cortejo bradando: "voltem para o tribunal, porque foi falso o testemunho desses homens contra ela!". ${ }^{8}$ Confusos, todos retornaram atabalhoados. Os chefes de família, conhecidos como Senhores do Conselho, demandaram explicações consistentes. No entanto, Daniel pretendia que as narrativas dos próprios velhos demonstrassem suas incoerências, razão pela qual interferiu no processo penal. Afastou-os, para que fossem interrogados em separado e na frente da assembleia e, com um jogo de argumentação acerca do que os velhos teriam visto, conseguiu que as respostas fossem contraditórias, provando "de suas próprias bocas"9 a inocência de Susana.

Os velhos juízes foram julgados de acordo com a lei de Moisés, ${ }^{10}$ e com eles se fez aquilo que se faria a Susana: foram condenados à morte por apedrejamento. "E, desde esse dia, Daniel teve grande prestígio entre o povo". "1 Susana, por sua vez, tornou-se síntese de retidão, por haver enfrentado e sustentado com fortaleza as injustiças do mundo, graças à sua fé.

A história de Susana enseja diversas interpretações e suscita múltiplos problemas. Interessa, entretanto, estabelecer relações do episódio com o arcabouço jurídico-moral que viabilizou seu manejo nos séculos XVI e XVIII. O propósito deste artigo é elencar uma série de questões em torno do episódio bíblico em tela para, a partir dele, propor uma reflexão acerca de suas representações e possíveis instrumentalizações. Finalmente, busca ainda estabelecer conexões e tensões entre as justiças senhoriais (ou particulares) e a justiça régia, enfatizando as relações necessárias entre essa última e o exercício do poder régio.

Para que seus propósitos pudessem ser alcançados, o artigo foi seccionado em cinco partes, além dessa introdução e da conclusão. De antemão, parece pertinente apresentar algumas das representações da temática na pintura de época com a finalidade de sublinhar que as imagens não eram produzidas gratuitamente, mas se subsumiam a projetos ou intenções de motivação políitica. ${ }^{12}$ Em seguida, trata-se de analisar alguns elementos presentes no episódio, de maneira a 
evidenciar, posteriormente, as formulações discursivas dele decorrentes. Na terceira parte, dois outros ingredientes são destacadamente examinados, a prudência e o segredo, indispensáveis para a reflexão em torno da cultura político-jurídica no Antigo Regime. Na sequência, o texto aproxima-se de seu ponto fulcral ao se debruçar sobre as relações entre os magistrados e a noção de bom governo do rei. Finalmente, enfrenta essa questão na última parte, quando discute os significados de uma justiça sumária e as conexões e tensões que estabelecia com a afirmação do poder régio. As considerações finais são uma síntese do conjunto argumentativo.

enquadramento teórico para a interpretação do episódio reside em grande medida nas contribuições que António Manuel Hespanha aportou para a história do direito e para suas representações no Antigo Regime, sobretudo de matriz coorporativo-escolástica. Segundo o autor, nesse paradigma, a ordem social, com sua hierarquia dada pelos séculos, era conformada por preceitos advindos do jusnaturalismo de matriz tomista. Cabia ao rei conferir harmonia por meio do ato de "dar justiça" - aos corpos sociais, garantindo os direitos e deveres característicos de uma justiça equitativa, traduzida na máxima de "dar a cada um o que é seu". Em consonância, o bom governo do rei, para conduzir a comunidade ao seu destino metafísico, devia respeitar os estatutos particulares e prerrogativas consideradas próprias de cada parte dessa sociedade-corpo. ${ }^{13}$ A própria noção de governar se confundia com a de conservar uma ordem social pautada em estados, na qual cada estrato correspondia a uma autonomia inerente. A jurisdição, capacidade de dizer o direito, conectava distintas esferas de poder, conferindo certo equilíbrio a essas partes constitutivas e concorrentes. ${ }^{14}$ Em outras palavras, o rei era o único que estava capacitado a gerir desigualdades, vinculadas, em geral, aos desígnios da própria natureza.

Como decorrência de uma teoria jurídica pluralista e relativista, o direito penal admitia uma função muito mais simbólica ou imaginativa do que exatamente disciplinar. Intencionava, antes, afirmar determinados valores sociais e aspectos de uma moral religiosa estruturante do poder. $\bigcirc$ próprio poder político se confundia assim com o catolicismo e o direito. ${ }^{15}$ A eficácia dessa cultura política "juridizada" se fundamentava em uma dupla ação, "de se fazer temer, ameaçando; de se fazer amar, não cumprindo". $\bigcirc$ equilíbrio dos afetos presente nessa fórmula se sustentava à medida que as ameaças não fossem mantidas de modo permanente e que fossem particularmente apreciadas sob a ótica benevolente e misericordiosa do soberano, ainda que apenas existente no campo do imaginário. ${ }^{16}$

Esses modos de ameaçar e perdoar deveriam ser comunicados e propalados pela arquitetura de poder de tal maneira que as imagens se tornariam um poderoso instrumento da coroa. Qual a relevância de se recuperar um episódio religioso
13. Xavier; Hespanha (1993, p. 121-145).

14. Cardim (2017, p. 14-15).

15. Cf. Paiva (2009).

16. Hespanha (2012, p. $151-$ 154). 
17. Prodi (2005, p. 341-351).

18. Hespanha (2011, p. 2122).

19. Chartier (2002, p. 215229). presente em imagens dessa época? Episódios bíblicos e proféticos imiscuíam-se aos textos jurídicos para justificar e asseverar suas ideias. Segundo Paolo Prodi, ainda que o direito canônico e o civil concorressem, também se enredavam, a exemplo das urdiduras entre poder espiritual e temporal. ${ }^{17}$ Em Portugal, por exemplo, tal entrelaçamento permitia que os graduados pela Faculdade de Direito (Leis e Cânones) da Universidade de Coimbra assumissem cargos tanto na carreira eclesiástica como na administração régia. ${ }^{18}$

Forte instrumento de propaganda, rápido e impactante, a arte era agora alçada para a pauta de governantes e seus conselheiros. Em algumas décadas, as imagens inundarão palácios e salões; presidirão cerimônias das mais diversas; circularão sob forma de retratos oficiais trocados entre cortes; figurarão em moedas e outros suportes; e, por meio de uma simbologia própria, indicarão uma pluralidade de advertências moralizantes.

Roger Chartier publicou um texto programático propondo questões para as reflexões e investigações sobre as "formas culturais" do "Estado moderno". ${ }^{19}$ Nessa oportunidade, lembrava que as monarquias medievais e modernas, apesar de disporem de um rei e sua corte, guardavam muitas diferenças. Essas se resumiam não apenas às distintas formas de remunerar os serviços dos vassalos Ide uma remuneração em terras, ao longo da ldade Média, para uma remuneração monetária, conforme já salientara Marc Bloch), mas também ao estabelecimento de uma série de dispositivos inéditos que, a partir de finais do século XV, começaram cada vez mais a se tornarem proeminentes: a presença do registro escrito como forma de divulgar intenções e formalizar processos de deliberação; o desenvolvimento dos arquivos e bibliotecas; a edificação de palácios monumentais; a difusão do selo régio; a recorrência de ciclos de pintura; a construção de galerias decoradas etc.

As monarquias do Antigo Regime, ainda segundo Chartier, passavam a ter de dispor de uma certa consciência de si, assim como deviam se mostrar capazes de comunicar sua própria história. Essas novas tecnologias a serviço do poder, das quais a arquitetura e a arte eram essenciais, contribuíam para que pudessem reiterar sua legitimidade e representar seu poder - necessidade imperiosa e permanente - seja pela ordem dos discursos, dos signos, ou ainda das cerimônias.

Dispostas essas considerações introdutórias, vejamos então algumas das representações mais comuns acerca do episódio em perspectiva. 
Museu de Arte de São Paulo possui uma gravura que representa Suzana no banho surpreendida pelos velhos, de meados do século XVI (Figura 1). Na imagem, Susana banha seus pés em uma simples fonte, enquanto os velhos discutem a pertinência de abordá-la nessa ocasião. Destaca-se ainda a cidade imaginária que serve de pano de fundo para o enredo. É impossível não aludir ao grande relógio de sol em plano intermediário aos personagens, possivelmente indício de temperança que prenuncia um complexo de forças de ação e reação. De um lado, a ausência de destemperança dos juízes, incapazes de submeter suas paixões positivas; do outro, Susana, que devia se imbuir de temperança para agir de occasio. Na verdade, tal representação é apenas uma de muitas que, com distintos atributos, versam sobre essa temática.

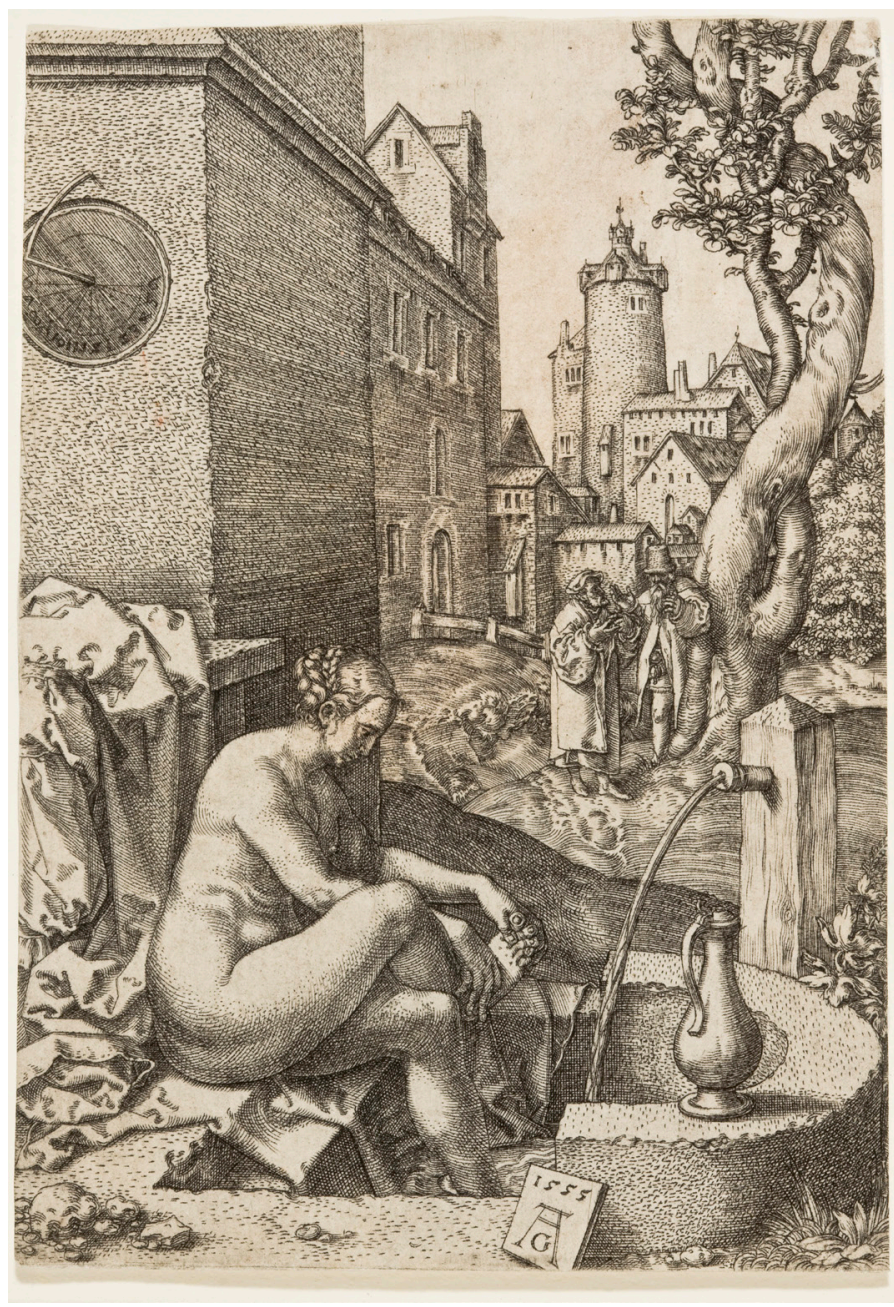

Figura 1- Heinrich Aldegrever, Suzana no banho surpreendida pelos velhos, 1555. Gravura a buril sobre papel, 1 1,3 $\times 8 \mathrm{~cm}$. Fonte: Acervo do Museu de Arte de São Paulo Assis Chateaubriand. 
20. Prevalecia nas artes o que ficou conhecido como o grand gôut, que surgiu com o Renascimento, diretamente ligado à ascensão do clássico, e compreendia uma tradição de representação de cenas históricas, com grande destaque para as batalhas, mitologia ou representações do antigo e do novo testamento. Argan (1999, p. 17-54).

21. Welch (2000, p. 79).

22. Brown (2005, p. 45).

23. Cf. Sabatier (2010).

24. Pereira (1995, p. 332340).

25. Cf. Dessins de la Renaissance (2004). Disponível em: <https://bit.ly/3gqF1SU>. Acesso em: 2 set. 2019.
Em "Susana e os velhos", como em tantos outros temas, bíblicos ou não, que se difundiram na modernidade, é preciso observar que, sob os pincéis de diferentes artistas, há a introdução de formas e elementos diferenciados, de discrepâncias de ordem narrativa, assim como a incorporação ou exclusão de personagens, dentre tantos outros recursos representativos. ${ }^{20}$ Todavia, é errôneo aqui se concluir que as diferentes interpretações e representações pictóricas meramente se originem do gênio do artista. Vinculados a uma escola artística, ou mesmo fundadores de estilo próprio, devemos recordar que os artistas não possuíam liberdade plena de representação dos temas que thes eram encomendados. Ainda assim, não podemos julgar que esses artistas, por seguirem uma determinada tradição ou por executarem obras cujas encomendas eram atreladas a contratos - que definiam e explicitavam detalhes e atributos que deveriam nela figurar -, fossem menos hábeis ou reconhecidos naquela sociedade. Há evidências de que não só os patronos, mas também distintos observadores de suas obras eram sensíveis ao virtuosismo artístico, de maneira que a erudição e a inventividade eram tão prezadas quanto à capacidade técnica demonstrada pelo artista. ${ }^{21}$

É preciso observar que na península itálica renascentista ao final do século $\mathrm{XV}$, a prática do mecenato e do colecionismo artístico já estava instituída. Príncipes e prelados italianos amealharam coleções artísticas, que posteriormente pareceriam modestas em comparação ao vulto que as coleções régias tomariam a partir dos seiscentos. A partir desse modelo inicial, o patronato se engrandecia e fortalecia conforme crescia a aderência dos monarcas europeus. ${ }^{22}$

O que ocorre é que o próprio sistema de patronato da qual as artes dependiam, que provinha em geral da coroa e de pessoas a ela associadas, inscrevia o artista em certos limites, estabelecidos, de modo formal ou tácito, pelos comanditários da obra. ${ }^{23}$ Não podendo ser compreendidos como meros patrocinadores eruditos, os comanditários escolhiam os temas a serem retratados, inclusive sugerindo programas pictóricos, escrevendo textos que figurariam junto às imagens e, em alguns casos, elegendo a iconografia a ser utilizada pelos artistas. Um exemplo é o caso de uma série de obras encomendadas por D. Miguel da Silva, então bispo de Viseu, ao artista Vasco Fernandes, cujas pinturas evidenciam a forte influência humanística que compunham a visão de mundo do artista. No entanto, é sabido que os programas pictóricos e detalhes foram estabelecidos pelo próprio bispo. ${ }^{24}$ No limite, os comanditários eram aqueles que, literalmente, comandavam a obra a um artista, que, por sua vez, imprimiria certo estilo pessoal em torno do contrato. ${ }^{25}$

A partir dessas considerações, a atenção recai sobre os comanditários das obras sobre o episódio "Susana e os velhos", em especial sobre o intuito pelo qual 
foram pintadas, o local em que seriam exibidas, e as razões de escolha iconográfica, bem como sobre as permanências, os acréscimos e ajustes na narrativa bíblica original. Das inúmeras imagens existentes sobre a temática, elegemos aquelas que foram produzidas em espaços geográficos diversos, exatamente para evidenciar sua circulação nas cortes europeias. Um parâmetro secundário utilizado se relaciona com a presença de algum elemento distintivo, capaz de singularizar a imagem. Dessa forma, a partir desses critérios, três imagens foram privilegiadas para a reflexão aqui proposta sobre a relação artistacomanditário, bem como os seus possíveis usos e manejos do tema.

O óleo sobre madeira, de Lorenzo Lotto, firmado e datado Lotus pictor 1517 (Figura 2), apresenta um panorama peculiar do tema. Subordinado a uma visão diacrônica dos acontecimentos a partir da lógica medieval de representação de tempos múltiplos em uma mesma obra, Lotto nos permite acompanhar a integralidade da trajetória de Susana, desde o momento em que caminha ao jardim até a chegada de pessoas que entreouvem seus gritos. Outra referência à tradição pictórica medieval está no jardim fechado em que Susana se banha. Tais jardins denotavam pureza e virtuosidade daqueles que em seu interior se encontrassem, sendo largamente utilizados em representações da Virgem e outras santas. Para corroborar esse ponto, Lotto atribui um halo a Susana, ainda que ela nunca tenha sido santificada, e reforça a violência dos velhos que adentram um espaço que deveria ser inviolável. De outro modo, para além dos típicos trajes italianos da primeira metade do século XVI, endossados pelos personagens, a obra também apresenta outros fortes traços do renascimento na península. A perspectiva, que protagonizava a arte do período, conecta e articula o espaço privado do jardim murado com a paisagem natural do espaço público. Ao fundo, uma grande fortaleza se impõe no horizonte, como um atributo que parece explicitar a própria virtude da força que Susana demonstrará no momento mais crítico do episódio. Apesar de o comanditário da obra não ser conhecido, tem-se notícia de que ela fora produzida durante o período em que o pintor esteve ativo a serviço da república de Veneza. Desse modo, fazendo eco a Gloria Fossi, podemos pensar até que ponto a obra não alude ao bom governo da justiça na Sereníssima, já que na Bíblia ela se mostra implacável, desmascarando e condenando os velhos. ${ }^{26}$

Outra obra pertinente se trata de $O$ profeta Daniel e a casta Susana, pintada por Francisco Henriques (Figura 3), de origem flamenca, ativo em Portugal a serviço de D. Manuel I. Sabe-se que a obra fora encomendada pelo próprio rei, que em ordem régia datada de 5 de janeiro de 1509 instruiu Álvaro Velho, então vedor e recebedor das obras do mosteiro de São Francisco na cidade de Évora, a receber e alojar o pintor enquanto ele estivesse ocupado na execução de 
retábulos. ${ }^{27}$ Originalmente, a obra compunha o conjunto de painéis que ocupavam as capelas laterais da igreja de São Francisco de Évora, considerados um dos mais notáveis e belos exemplares da pintura manuelina.

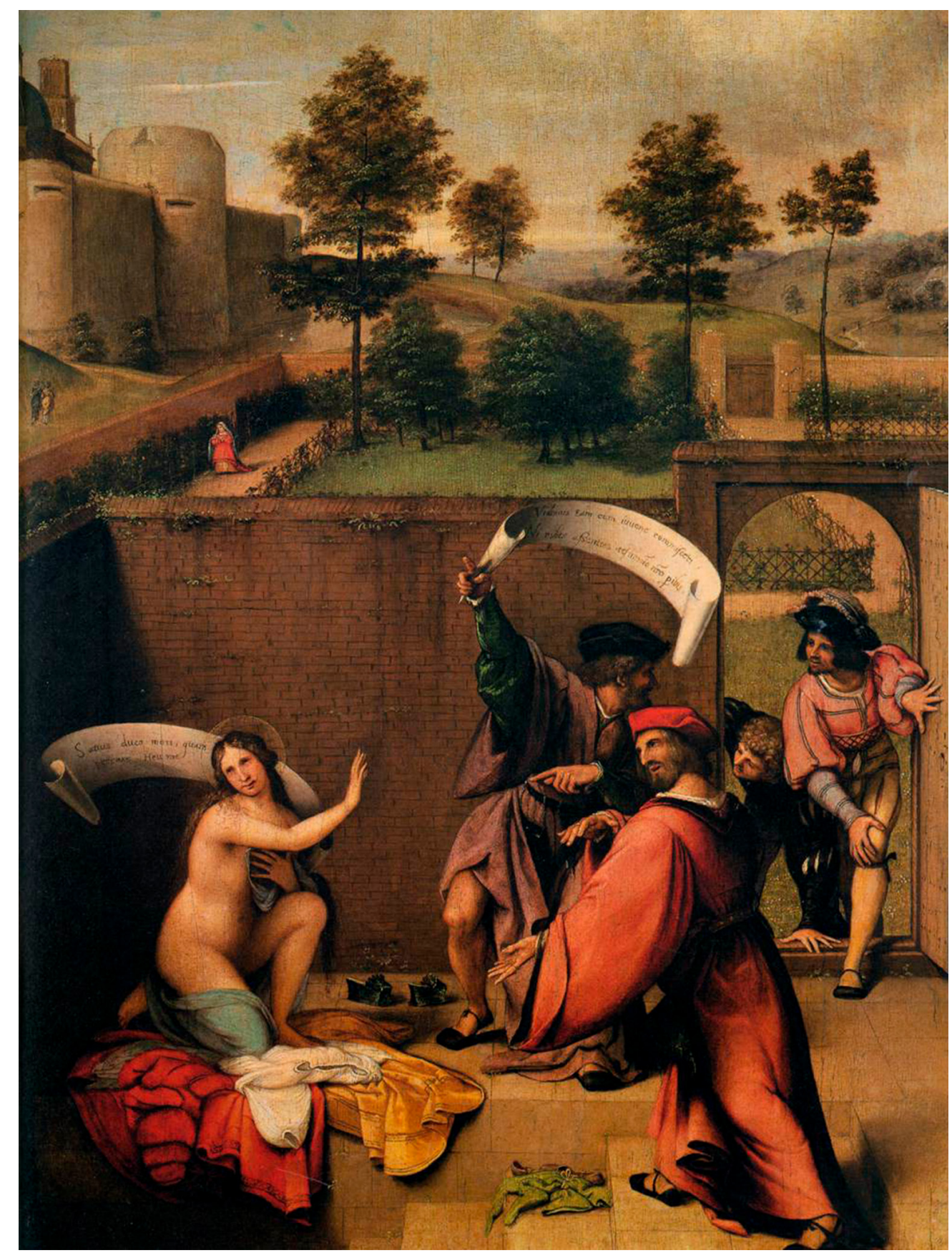

Figura 2 - Lorenzo Lotto, Susanna e i vecchioni, 1517. Óleo sobre madeira, 66 x 51 cm. Fonte: Acervo da Galleria degli Uffizi. 


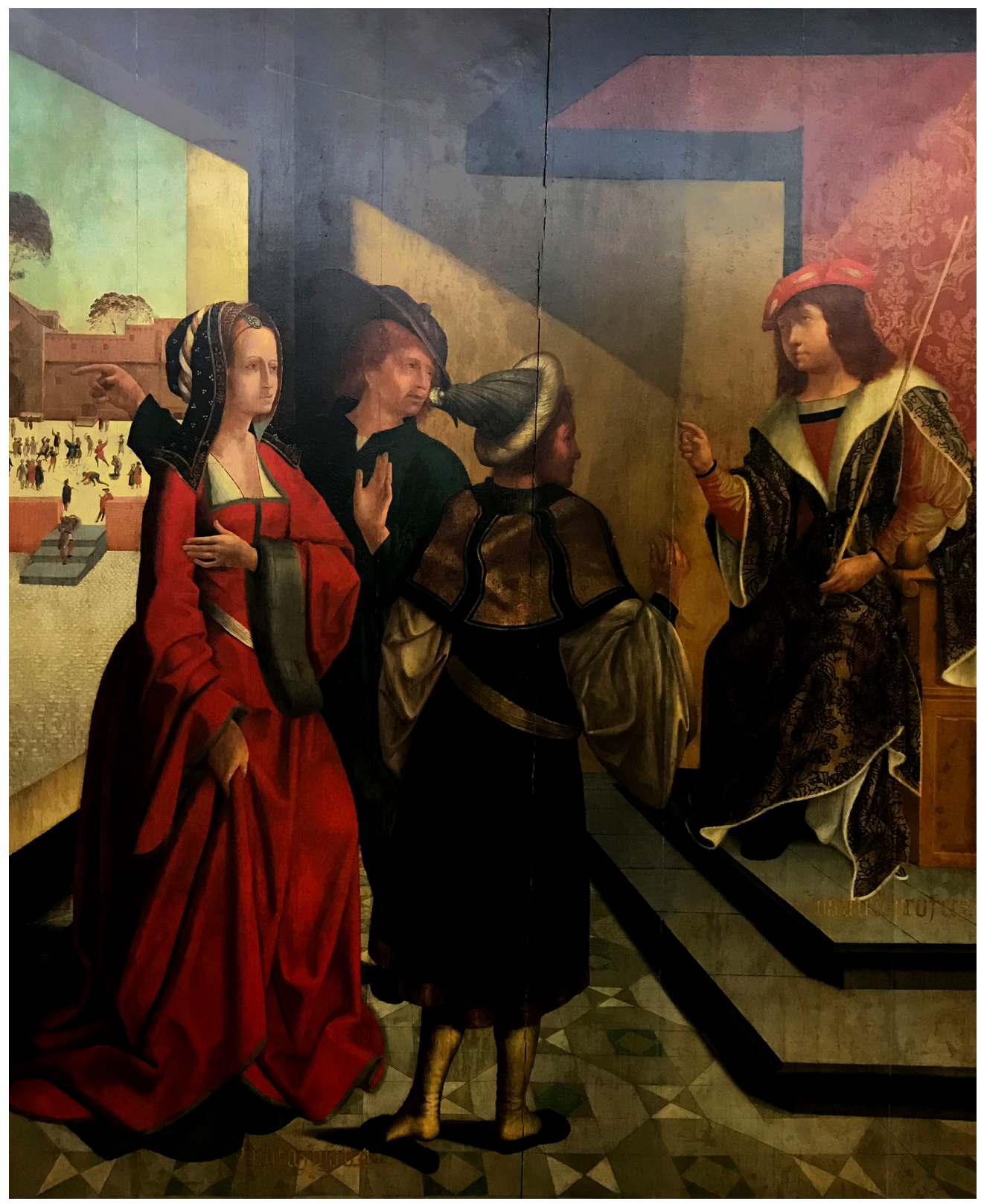

Figura 3 - Francisco Henriques, O profeta Daniel e a Casta Susana, 1509-1512. Óleo sobre madeira, 248 × 202 cm. Fonte: Acervo do Museu Nacional Frei Manuel do Cenáculo.

Representação incomum, a pintura de grande formato nos mostra o momento do segundo julgamento de Susana, conduzido por Daniel, em uma cena idealizada, bem diferente daquela narrada no texto bíblico. Nessa representação, Daniel não aparenta ser apenas o jovem cujo "espírito é despertado por Deus", mas sim a própria personificação da figura régia. Sentado sobre um trono, em patamar elevado, sob dossel ricamente decorado com tapeçaria adamascada, Daniel 
28. Acervo do Museu do Louvre (inv. 8245)

29. Luís XIV possuía algumas obras sobre este tema para além da já menciona$\mathrm{da}$, como as de Tintoretto, 1550 (inv. 568), e Véronèse, final do XVI (inv. 137). Ambas fazem parte do acervo do Museu do Louvre.

30. Como exemplo, a obra intitulada Susanna e i vecchioni, de Franchi Rossello di Jacopo, datada da primeira metade do século XV. Acervo da Fondazione Federico Zeri, Università di Bologna.

31. Acervo do Museu do Prado.

32. Cf. Braudel (2007).

33. Boucheron et. al. (2010, p. 49).

34. Para citarmos algumas obras intituladas Susana e os velhos em que podemos observar o signo harpocrático: Pieter Paul Rubens, 1602 (Galleria Borghese); Domenichino, 1603 (Galleria Doria Pamphilj); Artemisia Gentileschi, 1610 (coleção Graf Von Schönborn) e 1622 (The Burghley House); Guercino, 1617 (Museo del Prado); Guido Reni, 1620-25 (The National Gallery); Massimo Stanzione, 1630-35 (Städel Museum); Andrea Vaccaro, 1650 (Museo e Real Bosco di Capodimonti); Burrini Antonio, 1686 (Pinacoteca di Bologna). segura firmemente uma vara da justiça, símbolo do poder real. Se observarmos outras pinturas eucrônicas de D. Manuel I, podemos inclusive aproximar a imagem de Daniel a do próprio rei. Finalmente, a pintura portuguesa encerra o julgamento em ambiente fechado, ou seja, controlado e distante do espaço público onde os velhos são executados em segundo plano, novamente divergindo do texto genuíno.

Outras parcas representações feitas ao longo do tempo seguem a mesma senda da obra de Francisco Henriques, como L'innocence de Suzanne reconnue, pintada pelo francês Valentin de Boulogne em 1625,28 e adquirida por Luís XIV para compor sua coleção em 1662. ${ }^{29}$

Com significativa difusão no período moderno, "Susana e os velhos", que durante a ldade Média compunha em geral iluminuras e frescos menores, ${ }^{30}$ tornouse tema oportuno e cobiçado por comanditários e artistas por toda a Europa. Para além da já mencionada coleção de Luís XIV, podemos referir a de Felipe IV, que exibia em seu palácio El Escorial obra desse tema pintada por Guercino. ${ }^{31}$

É aqui importante ressaltar que, apesar de o tema ter circulado em diferentes localidades no início do século XVI, é ao final dessa centúria, em especial na península itálica, que ele ganhará vigor, irradiando-se para outras partes. ${ }^{32}$ Importantes artistas, como Peter Paul Rubens, Antoon Van Dyck, e o já citado Valentin de Boulogne pintaram suas versões do tema após uma passagem pela península.

Como deslindar a ebulição do interesse pelo tema na ltália e sua consequente irradiação? Um possível caminho para se elidir a questão é refletir sobre as consequências da acirrada concorrência entre diferentes regimes constritos na península itálica. A instabilidade resultante da fricção entre reinos e repúblicas de caráter diverso e convívio próximo levou a uma necessidade constante de reafirmação de seus governantes e políticas adotadas. Dessa forma, a justiça se tornava assunto nevrálgico, configurando-se como forte instrumento de persuasão e controle, de maneira que sua propaganda auxiliava na legitimação dos governos no poder. Paralelamente, essa concorrência acabava por promover um florescimento das artes, diretamente vinculado ao contexto políitico-cultural desses regimes. ${ }^{33}$

\section{O SIGNUM HARPOCRATICUM: UM EPISÓDIO SOBRE A PRUDÊNCIA DE SE GUARDAR SEGREDOS?}

Principalmente nas obras elaboradas no século XVII, ${ }^{34}$ podemos observar a recorrência do gesto harpocrático feito por um dos velhos juízes em algumas das 
representações dessa temática. $\bigcirc$ gesto, inspirado em Harpócrates, deus grego do silêncio e do segredo, consiste em levar um dedo aos lábios a exigir silêncio. Nas telas, geralmente se direciona à bela Susana, mas pode encontrar uma variação que interpela diretamente o observador da obra. ${ }^{35}$ Ora, no livro de Daniel, o trejeito em questão não pode ser encontrado na descrição narrativa, sendo, portanto, uma atribuição interpretativa ou atributiva do período em questão.

Em sua origem, o gesto sugeria que a divindade se calava para que pudesse dar voz ao coração, de maneira que os fiéis dotados da capacidade de silenciar sucederiam em perceber as lições implícitas nos discursos e nas histórias. É na época moderna, especialmente no contexto filosófico do humanismo, que o gesto se torna popular na iconografia, afastando-se de seu caráter propriamente religioso.

A laicização do gesto acaba por exteriorizá-lo, transformando-o em uma espécie de advertência que reforça a sabedoria presente na contrição do silêncio, como um apelo à cautela em uma época turbulenta, demandando cuidado para não se desvelar segredos. ${ }^{36}$ Cristalizado assim como uma virtude, o silenciar era ato aproximado da resignação, humildade, temperança ou prudência. ${ }^{37}$

Não custa ressaltar que o tema do segredo se desenvolveu na Europa medieval a partir de finais do século XIII, em uma conjuntura de plena mutação: o desenvolvimento da escrita adstrita aos assuntos de Estado; o nascimento dos impostos permanentes, que frequentemente exigiam do príncipe segredos concernentes ao tesouro régio; e, ainda, como contraposição à publicidade em torno de uma nova organização do poder centrada nos arranjos cortesãos. ${ }^{38}$ Nos quinhentos, com a consolidação da difusão da obra de Maquiavel, o segredo tornou-se um dos assuntos mais destacáveis da política e do governo, a ponto de muitos historiadores se debruçarem sobre os sentidos dos "arcana de Estado". 39 Nesse sentido, Maria Fernanda Bicalho, por exemplo, discute como existia uma vinculação entre segredo e justiça, ora de aproximação, ora de afastamento, sujeita às conveniências. ${ }^{40}$ Conforme ensina a autora, para muitos juristas e homens de política, a manutenção do segredo nos assuntos de Estado era uma necessidade indiscutível, a ponto de defenderem expedientes diferenciados de governação e diligência, a exemplo das juntas governativas, forma de deliberação mais célere e, por isso, mais eficiente em relação à guarda de arcanas. Ao reverso, para outros juristas, segredo e justiça tornavam-se práticas completamente inconciliáveis, uma vez que a circulação de informações nos órgãos da monarquia, a exemplo das secretarias e dos tribunais palacianos, garantia processos decisórios que confluíam para o suposto envolvimento dos ministros na formulação política.

Ao se referir ao segredo, Raphael Bluteau é quem nos orienta:
35. Schelling (2001, p. 200). 36. Chastel (2010, p. 85-86). 37. Cantarino (2013, p. 83103).

38. Santamaria (2018, p. 313-320).

39. Senellart (2006, p. 225).

40. Bicalho (2010, p. 343$371)$. 
41. Bluteau, 1728, v. 6, p. 548.

42. "Escandalizar: ofender com mau exemplo [...]. Escândalo: ação que ofende aos bons costumes [...]; palavra ou ação que dá ocasião a alguém à sua ruína espiritual; o pecado que alguém comete por sua malícia" (Ibid., v. 3, p. 206; Ibid., v. 7, p. 189-190).

43. Veiga (2017, p. 105).

44. Bluteau, op. cit., v.2, p. 474.

45. Bíblia, Livro de Provérbios, VIII, 12.
O superior, qualquer que seja, não pode mandar sob pena de excomunhão que se revele o que foi dito debaixo de segredo; exceto em dois casos, o primeiro, quando há perigo de execução de um crime, que envolve a ruína do público, ou também de algum particular [...] a razão é que a lei do segredo, posta por Deus, para o bem da sociedade humana, não foi feita para favorecer o mal, nem para encobrir conjurações contra o Príncipe, ou contra o Estado. ${ }^{41}$

Em "Susana e os velhos", os juízes demandam o segredo de Susana para que ela se submeta às suas vontades e esteja "em concórdia" com eles, sujeitando seu corpo à sua autoridade. Mas Susana grita, há escândalo, ${ }^{42}$ e por isso é levada a tribunal, em ato que Tomás de Aquino designaria por contumélia: insultar publicamente a outrem com palavras para macular ou privar sua honra. ${ }^{43}$ Seu segredo The negaria a justiça. Seja como for, em um primeiro julgamento (iudicium), o tribunal The é injusto, mas ainda assim romper o silêncio foi o único modo de delegar o desfecho ao ius civile ou, quiçá, a uma interferência divina. No caso, a intervenção transcendente se sobrepôs ao direito penal para asseverar seu refinamento processual.

Bastante claro parece, mas não custa lembrar que, em hipótese contrária, seu silêncio seria não apenas o pecado, mas a submissão eventual, ou mesmo rotineira, aos velhos, que poderiam doravante ameaçá-la sistematicamente. Em pecado, provavelmente reduzia as possibilidades de amparo divino que, conforme tal concepção de mundo, governa a história. Do que se trata "Susana e os velhos"? De uma alegoria de que o segredo "degola" a justiça, uma das máximas políticas dos quinhentos e seiscentos?

\section{DOIS VELHOS, DOIS JUÍZES: UMA CRÍTICA A UM CERTO MODELO DE JUSTIÇA?}

Na história constante em Daniel, um dos pontos que mais chama a atenção é o fato de os dois agressores serem não apenas idosos, como também juízes. Tradicionalmente, o ancião era alguém que devia ser respeitado, na medida em que guarda a autoridade conferida pelo tempo; e por isso aporta às circunstâncias uma experiência a ele imanente. Veja-se, por exemplo, mais uma vez o dicionário de Bluteau, em que a imagem do idoso aparece vinculada à ideia de conselho, já que um adágio lembrava: "Se queres bom conselho, pede-o ao velho". ${ }^{44}$

Conselho e prudência, por sua vez, atrelavam-se no pensamento tomista, sendo um o exercício preparatório para o outro. Em face do ofício de magistrado que os velhos exerciam, é possível ainda aproximar a sabedoria à justiça, como ocorre noutra fórmula bíblica: "Eu, o sábio, tenho por amigo a Prudência". ${ }^{45}$ Se recorrêssemos à 
gramática medieval, ficariam logo dispostas algumas das mais importantes ditas virtudes: a sapiência e a prudência, virtudes intelectivas; ${ }^{46}$ e a justiça, virtude moral.

A negligência em torno de outra virtude moral - a temperança - sintetizada na incapacidade de os velhos não refrearem suas paixões positivas, acabou por promover o desfazimento de todo o equilíbrio moral. $\bigcirc$ resultado se deslindou em um comportamento, ou uma "disposição da alma", em grau tão baixo que nem sequer poderia ser tipificado, conforme a escala proposta por Tomás de Aquino, como incontinente, senão vicioso, uma vez que desde o início os juízes intencionaram o ataque a Susana.

É preciso também salientar que o tribunal, que deveria ser o locus por excelência do bom governo, voltado para atingimento do bem comum, sofreu profundo desvio de finalidade, sendo degenerado em espaço de ameaça. Afinal, não foi a partir da invocação a uma acusação em tribunal que os velhos tentaram impor a concordância e o silêncio de Susana? Apesar disso, quando o testemunho do jovem Daniel pôde fazer emergir outra versão, ele mesmo determina: "voltem para o tribunal!". ${ }^{47}$ Noutros termos, ainda que o espaço do tribunal tenha se mostrado já uma vez palco da ameaça e, em seguida, insuficiente para apuro da verdade, todos retornam a esse espaço, afiançando a possibilidade de restauração de sua legitimidade. Era preciso que se demonstrasse, a partir de então, que os juízes declararam falso testemunho (falsa testimonia), ação considerada grave por Tomás de Aquino por ir contra o bem da boa fama, "o principal entre os bens exteriores". ${ }^{48}$ Sem paradoxo, a existência de um novo testemunho era ainda condição necessária para alteração da sentença. Mas apenas isso?

Não. Para poder alcançar a realização de um segundo julgamento, Daniel mobilizou o povo que, assombrado com a possível injustiça que passivamente presenciara, rapidamente se recolheu novamente em tribunal. Tentar calar Daniel era flertar com a possibilidade de acusação de tirania, já que o direito de comunicar (ius comunicantil era considerado parte do direito das gentes. No entanto, invocar a pressão popular nesse caso seria apenas um artifício óbvio para promover novo julgamento ou seria lembrar a tese de que no povo, membro do corpo político, reside um poder in habitu, potencializado e instrumentalizado em caso de necessidade contra o tirano? Ou seria ambos, na assertiva de que um decorre do outro de modo sinalagmático? Em última instância, foi o povo em assembleia - portanto, como representação do corpo da res publica - que asseverou a legitimidade do julgamento de Daniel, em detrimento de um julgamento anterior, do qual também foi partícipe. Noutros termos, em nome do bem comum, a condução da opinião da assembleia se deslocava dos magistrados para Daniel, agora sim instituído como representante
46. Krynen (1993, p. 204217).

47. Bíblia, Livro de Daniel, 13:49.

48. Veiga, op. cit., p. 130. 
49. Monteiro (2005, p. 526).

50. Martiré (2009, p. 12)

51. Calafate (2012)

52. Cottret (2009, p. 99-124).

53. Martiré, op. cit., p. 22. do povo, configurando-se assim uma certa simbiose entre o profeta e a assembleia, graças a uma unicidade discursiva em torno da ideia de justiça. ${ }^{49}$

De qualquer forma, o procedimento que se verifica no segundo julgamento é completamente distinto do primeiro. Na primeira ocasião, o ato é perverso, porque os juízes se sobrepõem de diversas jurisdições (testemunhar, acusar e julgar) para imputar falso crime (calumnia). Daniel, graças a um modus argumendi próprio, expõe socraticamente as contradições narrativas dos magistrados ao público. Sua autoridade, que antes poderia dispor da licitude da morte em nome do bem comum, agora estava constrangida e descreditada. Seu método, que abarca confutação e contradição, permite que a sentença válida, no limite, seja mesmo a do povo e não mais aquela dos magistrados. ${ }^{50} \bigcirc$ magistrado - agora o próprio Daniel - funciona como um mediador da voluntas popular que, por sua vez, pode reaver o poder (poder in habitu) se instalada a injustiça ou a tirania - nesse caso, a tirania da magistratura.

O episódio e a sua difusão não deixam, portanto, de se aproximar de discussões típicas dos séculos XVI e XVII. Qual a origem e o fundamento do poder régio? Reside no rei ou na comunidade politicamente perfeita? Se na comunidade, como alcança o rei? Como as respostas extrapolariam os propósitos deste artigo, resta apenas indicar que, para os tratadistas neoescolásticos, em geral, a origem do poder reside originalmente na comunidade. Uma vez politicamente organizada, desloca - por pacto - parcela de seu poder ao rei, mas o retém parcialmente, para atualizá-lo nos casos de tirania. Nessa especificidade, pode, em face de circunstâncias gravosas, transformar o poder in habitu em poder in acto, fazendo valer um direito legítimo de resistência. ${ }^{51}$ Em grau extremo, as contingências poderiam autorizar até o tiranicídio. ${ }^{52}$

\section{"SUSANA E OS VELHOS": UMA REFLEXÃO SOBRE A AUTONOMIA DOS MAGISTRADOS OU SOBRE SUA LEALDADE AO BOM GOVERNO DO PRÍNCIPE?}

O caso de "Susana e os velhos" também nos abre um precedente para refletir sobre a questão da autonomia dos magistrados. Ora, em face de uma justiça oficial do príncipe, o juiz só poderá efetivamente representá-lo nos processos de justiça se tiver competência delegada para julgar as causas em suas mãos. ${ }^{53} \mathrm{~A}$ noção de que os magistrados estavam inteiramente submetidos aos desígnios reais é leviana e nos conduz diretamente à questão dos problemas de consciência; afinal, se não há autonomia de julgamento, também não há formação e percepção da culpa. Conforme nos aponta Prodi, nos seiscentos, o assunto que versa sobre 
a relação entre a consciência e a lei se tornará questão primordial da qual se desenvolverão os conflitos entre indivíduo e poder. ${ }^{54}$

De todo modo, não podemos deixar de observar que a justiça possui algum controle próprio sobre suas práticas e seu corpus. De certa maneira, podemos inclusive pensá-la como precípua ao poder régio, já que é o responsável por moldar a justiça de acordo com suas particularidades e necessidades.

Ao nos voltarmos à história de Susana, deparamo-nos com as ações dos juízes, "envelhecidos em anos e crimes", que distribuíam "sentenças injustas, condenando o inocente e deixando livre o culpado". ${ }^{55}$ Eles são contrapostos à vigorosa iniciativa de Daniel, que critica a corrupção dos juízes.

A caracterização dos juízes nesses termos aponta para um problema de deontologia, fundamental em uma sociedade de Antigo Regime. Hespanha argumenta que toda autoridade, mesmo a do príncipe, estava sujeita e orientada por um código moral inscrito e implícito. ${ }^{56}$ Há, portanto, um "múnus próprio" de cada ofício, tecido ao longo dos séculos e reproduzido pelo costume, conforme uma ética católica. Entretanto, embora houvesse o costume, somado ainda a uma "literatura de natureza ética", verifica-se que a autonomia dos agentes era ponderável quando apreciavam casos concretos. Por isso, em uma sociedade de Antigo Regime, era comum ser acusado por "prática especiosa do ofício", sendo frequentes as acusações que abrangiam críticas ao comportamento moral dos oficiais. Distintamente do que se observa no caso de Susana, o resultado dessas acusações, por sua vez, costumava ser incerto. Contudo, o fato é que, quando os sindicantes pertenciam à mesma corporação dos acusados, havia pouca confiança na eficácia do processo.

Assim, na história da fiel Susana, dois julgamentos são narrados: o primeiro, coordenado pelos velhos juízes, e o segundo, liderado por Daniel, que não dispunha de delegação formal para julgar, mas teceu sua autoridade nas relações sociais e na própria conjuntura que provocou. Como já assinalamos, os procedimentos adotados em cada julgamento diferem na forma em que foram conduzidos. $\bigcirc$ primeiro contou com o testemunho exclusivo dos velhos juízes, que não encontraram oposição da assembleia formada pelos senhores do conselho e do povo que thes assistia: afinal, a avançada idade e a autoridade que representavam denotavam sabedoria e credibilidade. Na lógica aristotélica, todos teriam sido vítimas de uma falácia de indução por argumento de autoridade.

Seria, portanto, a apropriação da história de Susana uma oportunidade de o príncipe ou autoridades governativas locais advertirem seus magistrados? Seria a história bíblica convertida em instrumento pedagógico dos governos de Antigo
54. Prodi, op. cit., p. 13.

55. Bíblia, Livro de Daniel, 13: 52-53.

56. Hespanha (2011, p. 14). 
57. Bíblia, Livro de Daniel, 13:59.

58. Em referência à clássica iconografia da alegoria da Justiça e de atributo do poder régio.

59. Prodi, op. cit., p. 219.
Regime? Levando-se em consideração a popularização das imagens que aludem à história de Susana, que figuraram em palácios e outros ambientes com grande circulação de letrados, parece apropriado questionar se o tema de certa maneira não se refere a uma advertência do príncipe aos seus magistrados ou à sua nobreza. Apesar de as representações do tema se limitarem, em grande maioria, ao momento da abordagem de Susana pelos velhos, está implícito na obra o desfecho do episódio. Os magistrados deveriam seguir retos em suas condutas, sob risco de um dia se encontrarem no lugar dos velhos juízes condenados à morte, agora não mais sob a espada do "anjo de Deus", 57 mas sim sob a espada do próprio rei. ${ }^{58}$

Cada vez mais, a partir do século XVI, O "foro da consciência" vinculará os súditos à devida obediência demandada pelo soberano e, pari passu, vinculará também o próprio soberano, mantendo-o mais restrito ao cumprimento dos pactos e liberdades de seus vassalos. Ainda que mantenha certa autonomia, o príncipe, ou genericamente como coloca Prodi, quem representa a res publica, detém o "poder de promulgar leis que vinculem a consciência dos súditos". ${ }^{59}$

Nessa mesma senda, ao nos referirmos à questão da consciência pela lógica seiscentista, não podemos deixar de lado a concepção de crime e sua natureza, que se imbricam com a ideia de pecado. Não custa insistir: trata-se de uma sociedade em que religião, política e direito se confundem plenamente. $\bigcirc$ crime não se enquadra apenas na dimensão legal, mas também na moral, já que a própria lei não pode ser presumida sem moralidade. Destarte as corrupções, descasos e omissões de magistrados se configurarem em crime, são também uma forma de pecado, afinal foram proferidos juramentos que não deveriam ser quebrados. Novamente, sob tais circunstâncias, os velhos juízes do livro de Daniel são duplamente pecadores. Além da cobiça e do falso testemunho contra Susana, os anciões também romperam seus votos juramentais enquanto magistrados e, do ponto de vista políitico, contribuíram para o escândalo, ícone do mau governo do príncipe.

\section{"SUSANA E OS VELHOS": A IMPRUDÊNCIA DE UMA DECISÃO SUMÁRIA? JUSTIÇA SUMÁRIA VERSUS ORDINÁRIA? QUEM É E ONDE ESTÁ O REI?}

Por fim, resta questionar o porquê de reis e comanditários apresentarem tamanho interesse nesse caso de (in)justiça. A sentença de condenação sumária dos juízes foi anulada pelo testemunho de Daniel, mas o episódio não se resume a isso. Daniel desvelou as incoerências das narrativas dos magistrados, método que os 
descredenciou diante do povo. $\bigcirc$ constrangimento do primeiro julgamento, anulado pela ação de Daniel, e a agitação social dele decorrente não procuram exatamente invalidar as decisões de caráter sumário? Se sumárias, as decisões e sentenças não revelariam, em última instância, um rei imprudente? Fernando Bouza, ao se debruçar sobre os processos de deliberação política na monarquia hispânica na virada do século XVI para a centúria seguinte, conclui que a morosidade do despacho não era percebida como sinal de ineficiência, senão como um respeito às formas que asseveravam a prudência políitica e, em decorrência, a legitimidade da governação. ${ }^{60}$

De qualquer maneira, para além da principiologia jurídica, é mister examinar também a forma pela qual o direito é instrumentalizado na prática, como é conferido seu uso, como se constrói ou se degenera. Certamente, os comportamentos são regrados por normas, jurídicas e costumeiras. Dimensões não excludentes no Antigo Regime, a prática social frequentemente compreendia e se conformava a um direito costumeiro, de maneira que os laços e práticas também eram capazes de regulamentar condutas e hábitos, criando uma interdependência entre ambas. Dessa maneira, cotejando um equilibrio entre práticas e direito, podemos perceber dois movimentos: de como a sociedade penetra os tribunais, resultando em normas, e de como as normas afetam os comportamentos sociais. Quando uma prática é inédita, constrói-se uma nova norma ou uma nova interpretação e uso de uma já existente, visando abarcar a necessidade que surge. ${ }^{61}$

Estudos recentes vêm demonstrando a pluralidade não apenas do direito, mas também das práticas em torno da administração da justiça. Para não se alongar em demasia, pode-se referir, por exemplo, uma coletânea de trabalhos que, em conjunto, explicita especificidades diversas em relação às práticas judiciais na América portuguesa: ausência de uniformidade em relação às atribuições administrativas dos agentes envolvidos, variações acerca do acúmulo de funções pelos magistrados, distinções acerca do número de magistrados, extensão de comarcas, etc. ${ }^{62}$

Conforme elucida Simona Cerutti, quando as práticas sociais se tornavam prevalentes em relação às jurídicas, acabavam por ensejar a aplicação de uma justiça sumária que, em geral, não atribuía supremacia aos especialistas do direito. Dessa forma, inscrevia-se nos poderes discricionários dos agentes e, mormente, no costume de uma determinada localidade. A justiça sumária, comum no universo de vilas e cidades do Antigo Regime, dependia apenas dos próprios protagonistas, prevendo uma simplificação dos procedimentos ordinários da justiça, mesmo que divergentes ou apoiados em complexa problematização ou controvérsia jurídica. Tornava-se a justiça, portanto, mais célere, graças à execução imediata da sentença expedida, sem necessidade ou oportunidade de apelo a tribunais superiores. Ainda que tal procedimento se destinasse a público heterogêneo, Cerutti sublinha a
60. Bouza (2018, p. 112 140).

61. Barth (1981, p. 14-31).

62. Bicalho, Assis e Mello. (2017, p. 16-17). 
63. Cf. Cerutti (1995).

64. Cerutti, op. cit., p. $137-$ 139.

65. Bíblia, Livro de Daniel, 13:48.

66. Antunes (2013, p. 28-29). questão da fragilidade do status social que esse público compartilhava: em geral, eram mulheres, órfãos, pobres, peregrinos ou mercadores. ${ }^{63}$

Nesse ponto, voltamos, pois, à história de Susana. A justiça clamada e conduzida pelos velhos é sumária, o que resulta errônea e imprudente, condenando uma inocente. Entretanto, se analisarmos mais acuradamente, poderemos perceber que os velhos desempenham diferentes papéis na narrativa, afinal, além de propriamente cometerem o crime, são simultaneamente acusadores, testemunhas e juízes do caso em lide. Nessa urdidura, se o rito processual foi maculado, não seria possível haver probidade nos resultados.

Quando nos debruçamos sobre o primeiro julgamento narrado na história de Susana, em que esta é rapidamente condenada à morte, podemos perceber que a ausência de provas não é impeditiva para a conclusão do caso. Novamente, detendo-se na noção do direito do Antigo Regime, perceberemos a parca importância das provas no processo judicial; nesse sentido, é o testemunho, com representação e privilégio jurídico, que ascende em importância nesse cenário. Apresentar testemunhas de boa reputação era algo essencial. Assim, o debate se abre para a relevância e a qualidade do testemunho, que dependem diretamente do quão digno é aquele que o concede. ${ }^{64}$ Aqui, é interessante refletir sobre os velhos juízes que condenam Susana, pois são eles também testemunhas do pecado que ela supostamente teria cometido. Contrariamente, Daniel, ao sair em defesa da "virtuosa" Susana, adverte ao povo que, acreditando apenas no testemunho de relevantes personagens, castigavam Susana sem "examinardes nem conhecerdes a verdade" .55

Desse modo, nesse momento da história, há uma reviravolta dos acontecimentos. Sendo justo todo aquele que age com justiça e retidão, tendo em vista que a justiça era tida não só como uma virtude, mas como potência que poderia ser percebida na comunidade por meio das condutas individuais, podemos refletir melhor sobre o que Daniel representa na narrativa. Ao compreendermos que a "justiça é uma qualidade, guardada no indivíduo, porém exteriorizada por meio da ação", também podemos concluir que ela é uma prática precípua à ordem, que constrói base e condições para a paz e concórdia dos povos, e, consequentemente é vinculada ao rei, sendo uma virtude dele esperada e demandada. 66

Para além, há mais a ser considerado, se pensarmos em uma oposição entre a justiça sumária, sem escritos e sem ruídos (sine strepitu), sem advogados ou procuradores, e a justiça ordinária, que por sua vez vai entender que a expressão e decisão sumárias se remetem a um procedimento arbitrário, e, portanto, contrário ao direito positivo. Se bem recordarmos, já no medievo a justiça e o direito se constituíam enquanto instrumentos de legitimação da existência da figura do rei. 
Poderia, desse modo, a justiça sumária se opor à justiça do rei? Ou, reformulando o problema, a interferência de Daniel no processo de Susana, cujo caráter é, portanto, extrínseco a ele, não representaria a própria interferência régia nas práticas locais de administração sumária da justiça?

\section{CONSIDERAÇÕES FINAIS: "SUSANA E OS VELHOS", A MORAL, O DIREITO, E A LEGITIMAÇÃO DAS MONARQUIAS DE ANTIGO REGIME}

A história de Susana versa sobre questões de justiça e suscita a necessidade de compreender os motivos pelos quais tantas obras foram nesses moldes encomendadas, quem foram seus comanditários e de que maneira a narrativa bíblica serviu de fonte para toda uma iconografia que daria corpo a um logos imbricado a uma mentalidade jurídico-política de Antigo Regime.

As representações pictóricas que retratam a história de "Susana e os velhos" podem ser encontradas com expressividade na segunda metade dos quinhentos e irão alcançar seu pináculo de produção no século XVII. $\bigcirc$ fato de verificarmos que pintores, provavelmente sob a demanda de seus comanditários, elegeram momentos distintos para representação (por exemplo, Susana ao banho, os juízes a exigir seu silêncio, Daniel no trono etc.) demonstra como essa história, ainda que dispusesse de um sentido mais geral, poderia ser manuseada conforme interesses contingentes. Poderia, por exemplo, oferecer a possibilidade de crítica ao segredo nos assuntos da política, tema frequentemente em discussão.

aspecto moralizante também perpassava as interpretações disponíveis em torno da história. Susana explicitou sua resistência contra grave adversidade, capaz mesmo de encerrar sua vida. Na linguagem tomista, exercitou assim a virtude cardinal da fortaleza, própria daqueles que fazem do resistir uma qualidade, traduzida por ação que faz suportar provações supremas por ideais mais nobres.

Apesar de estar em extrema necessidade, Susana não se desesperou, reafirmando publicamente sua crença no valor da graça divina. Segundo a lógica católica, o desespero (desesperatio) era uma "paixão" que residia na parte irascível da alma; era contrário à virtude teologal da esperança e, quando se instalava, indicava a fragilidade da confiança humana no providencialismo. ${ }^{67}$ Sem fé no ordenamento que Deus conferia às coisas, o desesperado estava instigado à rebelião e ao vício da ira. 
68. Bluteau, op. cit., v. 5, p. 696.

69. Bluteau, op. cit., v. 3, p. 139.

70. Vieira (2015, p. 61-62).

71. Bíblia, Livro de Daniel, 13:42-43.
É exatamente essa a moral depreendida do dicionário de Bluteau. Quando disserta sobre a "necessidade", o padre admoesta: "no aperto da necessidade, entregar-se à desesperação é desconfiar daquela piedosa onipotência, que aos servos sabe dar, em horríveis soledades, deliciosos hospícios". 68 No verbete "desesperação", salienta que "das nuvens mais opacas saem exalações. Em casos desesperados acode o céu aos que nele esperam". Depois, arremata e demonstra sua tese exatamente a partir do manejo da história da própria Susana: "indo a inocente Susana ao suplício, suscitou Deus um menino que the salvou a vida [e] a fama". Aos fiéis, recomendava assim uma postura estóica, já que "é glória da providência divina acudir quando menos se espera". 69 Nesse sentido, o desfecho do episódio de Susana, ao servir como exemplum de que haveria uma inteligência capaz de comandar a história, convidava à resignação e à passividade.

Discurso de semântica similar se encontra no Sermão de Santa Iria, proferido pelo padre Antônio Vieira em 1638, portanto, algumas décadas antes da publicação do dicionário de Bluteau. $\bigcirc$ jesuíta se debruça sobre o tema da calúnia e adverte que ela, embora "não tire ao homem o alvedrio, tira-lhe a fama e o põe em tentação de não fazer caso da Lei de Deus", evidentemente porque pode eliminar reputações e posições sociais. A calúnia não contribui assim para o bem comum, já que desesperados os homens deixam a lei de Deus e se dispõem a tudo. Mais uma vez, convoca-se o exemplo de Susana; porém, dessa vez essa história é incrementada com um ingrediente novo:

por excelentemente heroica louvam todos os santos a constância de Susana, caluniada e infamada [...]. Diz Santo Ambrósio que, acusada, Susana calava, porque tinha contra si o número e a idade dos seus acusadores [...]. Todos se compadeciam de Susana, e todos defendiam sua inocência, e ela, contudo, não se defendia, mas calava, porque os acusadores eram dois e ela uma, os acusadores velhos e ela moça. ${ }^{70}$

Curiosamente, se retomarmos o texto bíblico, podemos constatar que Susana não permaneceu em completo silêncio durante seu julgamento, já que após o depoimento dos velhos "Susana disse em alta voz: Deus eterno, que conheces o que está escondido e tudo vês antes que aconteça, tu sabes muito bem que eles deram falso testemunho contra mim". ${ }^{71}$ A afirmação dessa postura idealizada por Vieira pode estar vinculada à valorização (estratégica, moral-teológica e até estética) que o permanecer em silêncio recebeu na península ibérica dos séculos XVI e XVII.

Mas Susana, ainda segundo o padre, também se calou porque era "moça", razão igualmente condizente com a cultura ibérica que prezava, em especial, o 
silêncio feminino. Conforme tem demonstrado María Teresa Cacho, os autores de tratados dedicados à educação feminina se esforçaram por convencer as mulheres a admitir uma posição social secundária ou dependente de seus parentes e maridos. ${ }^{72}$ Em função dessa posição subalterna, as mulheres deveriam guardar silêncio, sob o risco de irritar seus maridos, expondo assim sua integridade física ou mesmo sua vida a risco. "Se teu marido te disser alguma má palavra, deixa passar, sofra com paciência [...]; dessa maneira, sofrendo, vencerás", escreveu, por exemplo, o tratadista Luis Vives em sua Instrucción de la mujer Cristiana, de 1528. ${ }^{73}$

Para endossar seus argumentos, esses tratadistas procuravam justificativas em diversos planos, desde a lei divina ou a doutrina cristã, que submete Eva a uma derivação de Adão, ou a responsabiliza pelo pecado original, até a observação da natureza. Para tanto, baseavam-se nos escritos de São Paulo ou em analogias apreendidas de Aristóteles, que chegou a consignar, por exemplo, que no universo natural das aves apenas os machos cantam, argumento por vezes extrapolado para a realidade humana. As advertências presentes nesses tratados eram explícitas: "o melhor conselho que podemos dar é rogar que se calem e que, já que são pouco sábias, se esforcem a ser muito caladas", como figura na obra La perfecta casada (1583), do tratadista Frei Luis de Leão. ${ }^{74}$

silêncio, índice de obediência, era assim considerado uma virtude. Assim, essas mulheres não deveriam nada temer, já que a providência tudo governa: "sofra a mulher e se cale, e ponha toda a sua esperança em Deus", na fórmula de Luís Vives. ${ }^{75}$ Em face desse contexto, parece plausível e conveniente que "Susana e os velhos" tenha sofrido essa adaptação.

De outra parte, se aceitarmos adequada a hipótese de que essa história também é uma alegoria do poder do príncipe que procura constranger a atuação de seus oficiais, categoria que evidentemente abarca magistrados, parece irresistível associar a difusão do tema ao processo de construção das monarquias europeias de Antigo Regime. Os velhos magistrados passaram rapidamente de guias do povo para réus, e o protagonista de sua derrocada foi Daniel, metáfora do próprio rei. Desnecessário sublinhar que a reputação dos oficiais régios devia se subscrever na anuência régia. Daniel, em contrapartida, "desde esse dia [...] teve grande prestígio entre o povo". ${ }^{76}$ Não se trata apenas de conferir relevância ao governo da justiça pela coroa, mas também submeter oficiais, prática normalmente tentada por regimentos e instruções. ${ }^{77}$ Para além, cabia à coroa procurar manipular um discurso jurídico mais coerente e conveniente aos seus interesses (ius propria). No caso em tela, o direito do rei se apropria de um episódio bíblico para se impor. Não custa insistir, uma vez mais, que se trata de um rei que precisa a todo instante reafirmar a legitimidade de sua presença e de sua supremacia e que, para ser
72. Cacho (2013).

73. Apud Ibid., p. 135.

74. Apud Ibid., p. 131.

75. Apud Ibid., p. 136

76. Bíblia, Livro de Daniel, 13:64.

77. Cf. Cosentino (2009). 
bem-sucedido nessa empreitada, deve eliminar os poderes intermédios e justiças senhoriais, caracterizadas, de modo costumeiro, por execuções sumárias.

Na história de "Susana e os velhos", arte e direito, práticas de significativa expressividade em seu próprio tempo, imbricaram-se. $\bigcirc$ rei, representado por Daniel, instrumento último do providencialismo, figura como forma implícita e imaginária de justiça - imaginária, aliás, tal qual uma imagem que comunica e legitima sua capacidade jurisdicional. Reforça-se, portanto, pela arte e pela propaganda, o poder do rei enquanto fonte de sabedoria e justiça. Como bem salientou o jurista Fulvio Maroi, ${ }^{78}$ a arte poderia funcionar como uma espécie de colaboradora do direito, aportando motivos para a vida jurídica cotidiana, síntese do ideal de justiça de uma época. Em certo sentido, a arte poderia, então, revelarnos profundas raízes do direito, pensado como "inquietude espiritual antes de ser ideia, intuição antes de ser noção, sentimento antes de ser norma". 


\section{REFERÊNCIAS}

FONTES IMPRESSAS

BÍBLIA. São Paulo: Paulus, 1990. p. 1162-1164.

BLUTEAU, Raphael. Vocabulario Portuguez e Latino [...]. Diversos volumes. Coimbra: Colégio das Artes da Companhia de Jesus, 1728.

VIEIRA, António. Obra completa do padre António Vieira. Direção de José Eduardo Franco e Pedro Calafate. Tomo II. Volume XI. São Paulo: Loyola, 2015.

LIVROS, ARTIGOS E TESES

ANTUNES, Álvaro de Araújo. As paralelas e o infinito: uma sondagem historiográfica acerca da história da justiça na América portuguesa. Revista de História, São Paulo, n. 169, p. 21-52, jul./dez. 2013.

ARGAN, Giulio Carlo. Clássico Anticlássico: o Renascimento de Brunelleschi a Bruegel. São Paulo: Companhia das Letras, 1999.

BARTH, Fredrik. Process and form in social life. London: Routledge \& Kegan Paul, 1981.

BAXANDALL, Michael. Padrões de intenção: a explicação histórica dos quadros. São Paulo: Cia das Letras, 2006.

BICALHO, Maria Fernanda. As Tramas da Política: Conselhos, secretários e juntas na administração da monarquia portuguesa e de seus domínios ultramarinos. In: FRAGOSO, João; GOUVÊA, Fátima (orgs.). A Trama das Redes. Rio de Janeiro: Civilização Brasileira: 2010. p. 343-371.

BICALHO, Maria Fernanda; ASSIS, Virgínia; MELLO, Isabele de Matos. Introdução. In: BICALHO, Maria Fernanda; ASSIS, Virgínia; MELLO, Isabele de (orgs.). Justiça no Brasil Colonial: agentes e práticas. São Paulo: Alameda, 2017. p. 1-21.

BILOU, Francisco. A Igreja de São Francisco e o Paço Real de Évora. Lisboa: Edições Colibri, 2014.

BOUCHERON, Patrick; BRIOIST, Pascal; CARRANGEOT, Delphine; TRAVERSIER, Mélanie. $L e$ Prince et les Arts: France, Italie XIV-XVIII siècles. Neully: Atlande, 2010. 
BOUZA, Fernando. Del Escribano a la biblioteca: la civilización escrita europea en la alta Edad Moderna (siglos XV-XVII). Madrid: Akal, 2018.

BRAUDEL, Fernand. O modelo italiano. São Paulo: Companhia das Letras, 2007.

BROWN, Jonathan. Felipe IV como mecenas y coleccionista. In: COBOS, Andrés. El palacio del Rey Planeta: Felipe IV y el Buen Retiro. Madrid: Museo Nacional del Prado, 2005. p. 44-62.

CACHO, Maria Teresa. Éduquer pour le silence. In: MERLE, Alexandra; GUILLAUME-ALONSO, Araceli (orgs.). Les vois du silence dans l'Espagne des Habsbourg. Paris: PUPS, 2013. p. 123-136.

CALAFATE, Pedro. Da origem popular do poder ao direito de resistência: doutrinas políticas no Portugal do século XVII. Lisboa: Esfera do Caos, 2012.

CANTARINO, Elena. Du silence de la raison aux raison du silence. Considérations pour une théorie du silence à l'époque baroque. In: MERLE, Alexandra; GUILLAUME-ALONSO, Araceli (orgs.). Les vois du silence dans l'Espagne des Habsbourg. Paris: PUPS, 2013. p. 83-103.

CARDIM, Pedro. Portugal y la Monarquía Hispánica. Madrid: Marcial Pons, 2017.

CERUTTI, Simona. Normes et pratiques, ou de la legitimité de leur opposition. In: LEPETIT, Bernard (ed.). Les formes de l'expérience: une autre histoire sociale. Paris: Albin Michel, 1995. p. 127-149.

CHARTIER, Roger. A história cultural: entre práticas e representações. Lisboa: Difel, 2002.

CHASTEL, André. Il gesto nell'arte. Roma: Laterza, 2010.

COSENTINO, Francisco Carlos. Governadores Gerais do Estado do Brasil (séculos XVI-XVII): ofício, regimentos, governação e trajetórias. São Paulo: Annablume, 2009.

COTTRET, Monique. Tuer le tyran? : le tyrannicide dans l'Europe moderne. Paris: Fayard, 2009.

FOSSI, Gloria. Galleria degli Uffizi: arte, storia, collezioni. Firenze: Giunti, 2017.

HESPANHA, António Manuel. A Monarquia: a legislação e os agentes. In: MONTEIRO, Nuno Gonçalo (org.). História da Vida Privada em Portugal. A Idade Moderna. Lisboa: Temas e Debates; Círculo de Leitores, 2011. p. 12-31.

HESPANHA, António Manuel. Caleidoscópio do Antigo Regime. São Paulo: Alameda, 2012.

KRYNEN, Jacques. L'empire du roi: idées et croyances politiques en France (XIII $\left.{ }^{\mathrm{e}}-\mathrm{XV}^{\mathrm{e}}\right)$. Paris: Gallimard, 1993. 
MAROI, Fulvio. Riflessi di diritto nelle arti classiche figurative. Modena: Società Tipografica Modenese, 1927.

MARTIRÉ, Eduardo. Las Audiencias y la Administración de Justicia en las Indias: de iudex perfectus al judex solutus. Buenos Aires: Historica, 2009.

MONTEIRO, Rodrigo Bentes. Aparente e essencial. Sobre a representação do poder na Época Moderna. In: SOUZA, Laura de Mello e; FURTADO, Júnia; BICALHO, Fernanda (orgs.). $O$ governo dos povos. São Paulo: Alameda, 2009. p. 519-538.

PAIVA, José Pedro. O Estado na Igreja e a Igreja no Estado: contaminações, dependências e dissidência entre o Estado e a Igreja em Portugal (1495-1640). Revista Portuguesa de História, Coimbra, t. XL, p. 383-397, 2009.

PEREIRA, Paulo. História da arte portuguesa. Lisboa: Temas e Debates, 1995. v. 2.

PRODI, Paolo. Uma história da Justiça. São Paulo: Martins Fontes, 2005.

SABATIER, Gérard. Le prince et les arts: stratégies figuratives de la monarchie française de la renaissance aux lumières. Seyssel: Champ Vallon, 2010.

SANTAMARIA, Jean-Baptiste. Le secret du prince: gouverner par le secret: France, Bourgogne $\mathrm{XIII}^{\mathrm{e}}-\mathrm{XVI}^{\mathrm{e}}$ siècle. Ceyzérieu: Champ Vallon, 2018.

SCHELLING, Friedrich Wilhelm Joseph. Filosofia da arte. São Paulo: Edusp, 2001.

SENELLART, Michel. As artes de governar. São Paulo: 34, 2006.

VEIGA, Bernardo. A ética das virtudes segundo Tomás de Aquino. Campinas: Ecclesiae, 2017.

WELCH, Evelyn. Art in Renaissance Italy. Oxford: Oxford University Press, 2000.

XAVIER, Ângela Barreto; HESPANHA, António Manuel. A Representação da sociedade e do poder. In: HESPANHA, António Manuel (org.). História de Portugal. O Antigo Regime (16201807). Lisboa: Círculo dos Leitores, 1993. p. 121-145.

SITE

DESSINS de la Renaissance: Artistes et Commanditaires. Bibliothèque Nationale de France, Paris, 10 abr. 2004. Disponível em: <https://bit.ly/3gqF1SU>. Acesso em: 2 set. 2019. 
Artigo apresentado em: 22/09/2020. Aprovado em: 08/02/2021. (c) BY All the contents of this journal, except where otherwise noted, is licensed under a Creative Commons Attribution License 